\title{
Transportation planning and its interface with spatial planning and environmental management: the position within South Africa
}

\author{
C. B. Schoeman \\ North West University (NWU), South Africa
}

\begin{abstract}
The interface between transportation planning, spatial planning and environmental management forms the focal point to attain sustainable development. The principle of sustainable development is not a new phenomenon being applied by professional practitioners. Many role-players have realized that there is a delicate balance between transportation, land use, environment, human, economic, institutional, and spatial planning, management and development.

This balance is however negatively being impacted upon, due to the collapse of this relationship. This results in impacts such as a non-understanding of the integrated role of transportation, spatial planning and environmental management resulting in ecological degradation and widening of development inequality.

The purpose of the paper is to assess and investigate the interface between transportation planning, spatial planning and environmental management from a practice, educational, training and development perspective as it is being experienced in South Africa.

The conclusions consist of recommendations to grow and built this interface. It includes improved integration of the policy and legislative frameworks; capacity building amongst the different professions; improved alignment in education, training and professional practice and integrated simulation and modeling techniques, methodologies and the need to formulate of transdisciplinary plans as to promote the integration of the interface.
\end{abstract}

Keywords: transportation planning, land use planning, spatial planning, environmental management, modeling, simulation and trans-disciplinary planning. 


\section{Introduction and background overview}

Transportation planning, spatial planning (land use planning) and environmental management form a pivotal role in attaining sustainable development within spatial systems. The principle of sustainable development is not a new phenomenon within the built and natural environment.

Most practitioners have realized that there is an intricate balance between environment, human, economic, institutional, spatial and transportation planning and development. This balance is however negatively being impacted upon due to the collapse of this relationship mainly due to planning practices being applied by practitioners within these related professional fields. This results in impacts such as ecological degradation and widening of development inequality. It also implies spatial non-sustainability and conflicts in physical planning and development.

With democratisation in South Africa in 1994 the New Government inherited a segregated and fragmented policy and legislative framework guiding transportation planning, spatial planning and environmental management. Transformation formally commenced with the Draft Green Paper on Development and Planning prepared by the National Development and Planning Commission in 1999 [1]. However, the need and principles for integration of transportation planning, spatial planning and environmental management was included in the Development Facilitation Act (1995) [2] and the South African Constitution (1996) [3].

\section{Policy and legislative framework guiding spatial planning: transport and environmental management}

\subsection{Transportation planning}

Transport planning in South Africa became a statutory planning activity with the enactment of the Urban Transportation Act (Act 78 of 1977) [4]. Transportation planning, development and management were guided by the following core policy and legislative framework: National Land Transport Transition Act (Act 22 of 2000) [5] up to 2009 when the National Land Transport Act and its Regulations (2009) [6] were promulgated. In this context various policy documents underpinned this transformation process: White Paper on National Transport Policy (1996) [7]; Moving South Africa (Vision 2020) (1999) [8]; Rural Transport Strategy for South Africa (2003) [9] and the National Transport Master Plan 2050 (NATMAP 2050) (2011) [10].

\subsection{Spatial planning}

The development implications of the historical spatial planning and development practices in South Africa have been well documented by various researchers including Dewar et al. [11], Tomlinson et al. [12], Swilling [13], Mabin and Smit [14], Planact [15], Tilman and Wall [16], Dewar and Todeschini [17], CSIR [18], 
White Paper on Spatial Planning and Land Use Management [19], Spatial Development Perspective [20] and the Final Draft of the Land Use Management Bill [21].

Of significance in the transformation process related to spatial planning (land use) and development was the promulgation of the first new set of democratic laws that served as pivotal point to restructure the characteristics of spatial planning in South Africa namely the Development Facilitation Act [2]. Refer also to the Constitution of South Africa [3].

Eventually the spatial planning scene changed significantly with the promulgation of the Municipal Structures Act [22] and the Municipal Systems Act [23]. This development resulted in the formulation of Integrated Development Plans (IDPs) for all institutional entities within the municipal sphere of government.

\subsection{Environmental management}

South Africa was slow to develop and institute formal procedures for environmental assessment. It was only with the enactment of the Environment Conservation Act [24] that provision was made to determine environmental policy to guide decision-making and to prepare environmental impact reports (Sowman et al. [25]). The publication of a document entitled Integrated Environmental Management (IEM) in South Africa (Council for the Environment [25] marked the introduction of the concept of environmental management in South Africa. The term IEM was chosen to indicate a general approach that integrates environmental considerations across all stages of the planning and development cycle and would be applicable to policies, programmes, plans and projects (Sowman et al. [25]).

The publication of the National Environmental Management Act (NEMA) [27] introduced new approach to and role of environment in development. NEMA provides the framework for co-operative environmental governance in South Africa and promotes the application of environmental assessment and management tools to ensure integrated environmental management of activities (DEAT [28]). The intention of NEMA was formalized through publication of the EIA Regulations [29]. On 3 August, 2010 the revised NEMA EIA Regulations [30] were promulgated that includes chances in the listing of activities.

Based on the reality as summarized above problems and challenges related to the interface between spatial, environmental and transportation planning processes in South Africa is a well known area of debate. Practitioners in these disciplines within the public and private sectors have interpreted the interface for different reasons in various ways. The evolution over the past decade of policy and legislative frameworks (as indicated above) directing these processes did not necessarily promote a common understanding the interface between the processes involved.

From an assessment of the content of the policy and legislative framework the conclusion can be drawn that restricted provision for the integration of the interface between the professions exists. As an example in the case of the National Land Transport Act [6] provision is made in Chapter 4: Transportation 
Planning that in terms of general principles transportation planning and its integration with land use and development planning should be provided for. This provision, although very general and of a pure philosophical nature, should be read with the objectives as identified in the National Framework for Sustainable Development in South Africa [31] that makes provision for enhancing systems for integrated planning and implementation; sustaining ecosystems and using natural resources efficiently; economic development via investing in sustainable infrastructure; creating sustainable human settlements and responding appropriately to emerging human development, economic and environmental challenges.

The problem from an interface perspective between the professions relates to the fact that the policy and legislative framework can be classified as complicated; confusing and incomplete. The lack of a comprehensive and overarching guideline document to promote and integrate planning and development processes can clearly be deduced.

\section{The domain of transport planning, spatial planning and environmental management from an integration perspective}

Universally planning in general entails the consideration of what can and should happen where in spatial systems. It includes the investigation and interaction of different policies and practices across regional space, and sets the role of places and various other practitioners in a wider context. It goes well beyond 'traditional' transportation planning, land-use planning and environmental management practices and includes a strategic framework to guide future development and policy interventions. Table 1 shows a classification of the core focuses for planning in general based on the international and national norms applicable.

\section{Education and training practices in managing the interface}

Global realities, tendencies and developments form an important focus in the education and training practices underpinning transportation planning, spatial planning and environmental management practitioners. The core focus in these professions is to produce critical thinkers and not practitioners who implement existing planning policy and practices without considering moral grounds, ethical issues and other applicable planning related elements and implications.

The development of objectivity, creativity, innovative and critical thinking forms the foundation for integration of transportation planning, spatial planning and environmental management practitioners.

Preparedness of the integration of the professions in the 21 st Century relates to the ability to address global, national, provincial and local challenges within spatial systems. This ever changing environment is the key driver to address 


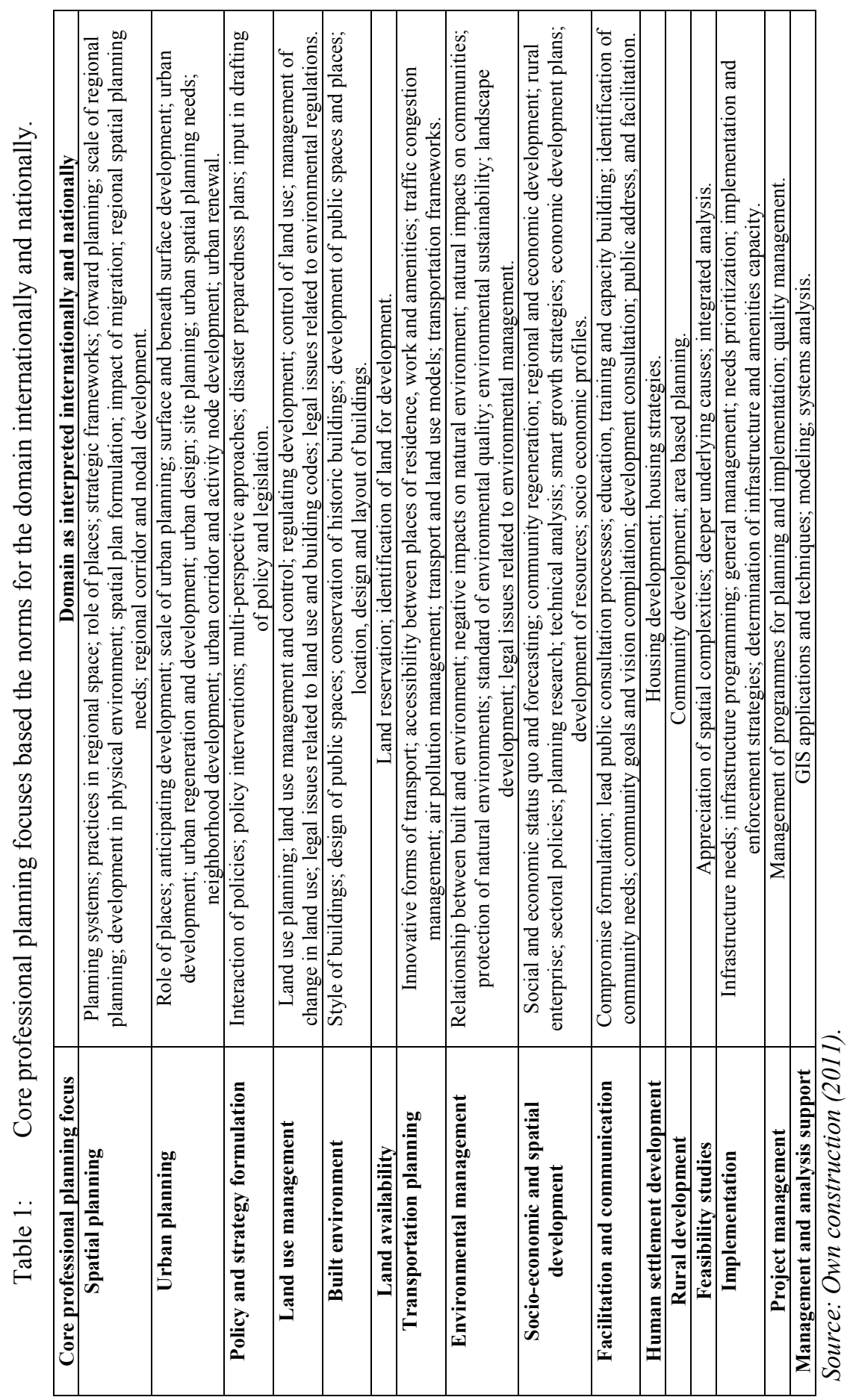


planning and development challenges in a sustainable fashion. This dynamic environment requires ongoing analysis to ensure that these challenges are being addressed in a timely and optimal fashion.

In essence it requires that the management of transportation planning, spatial planning and environmental management incorporates elements of visionary but inclusive approaches to depict needs, to re-act to such needs and the application of integrated management and approaches between such disciplines.

It includes optimization of disciplinary (discipline), multi-disciplinary, interdisciplinary to trans-disciplinary approaches based on inter-disciplinarily and stakeholder participation processes (refer to Fry et al. [32]) for further background).

This process is also fundamental to the formulation of Integrated Development Plans (IDP's) in applied in South Africa. However, the integration of the professions in terms of the preparation of sectoral plans is still disjointed and shows limited levels of real integration and trans-disciplinary involvement.

Figure 1 shows the scope of inter-active disciplinary approaches to promote the interface between transportation planning, urban and regional planning, and environmental management with stakeholder involvement in an endeavor to promote sustainable development.

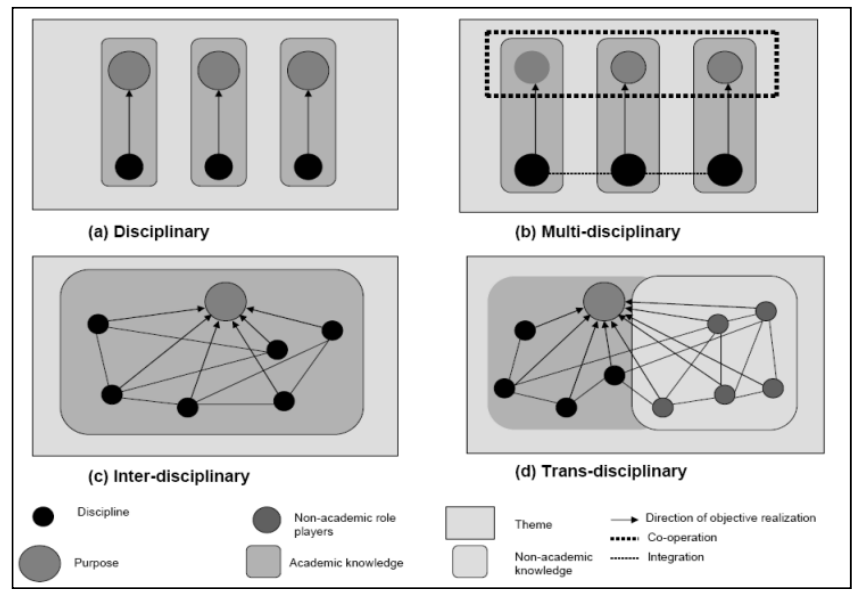

Source: Fry et al. [32].

Figure 1: Application of disciplinary approaches in promoting the interface between disciplines.

The ultimate goal is to guide the approach, thinking and insight capabilities of professionals and researchers based on the complexity of functional involvement and strategic level as being illustrated in Figure 1. Within the context of integration it involves the promotion of the process of insight and thinking development ability between the professions (Figure 2). 

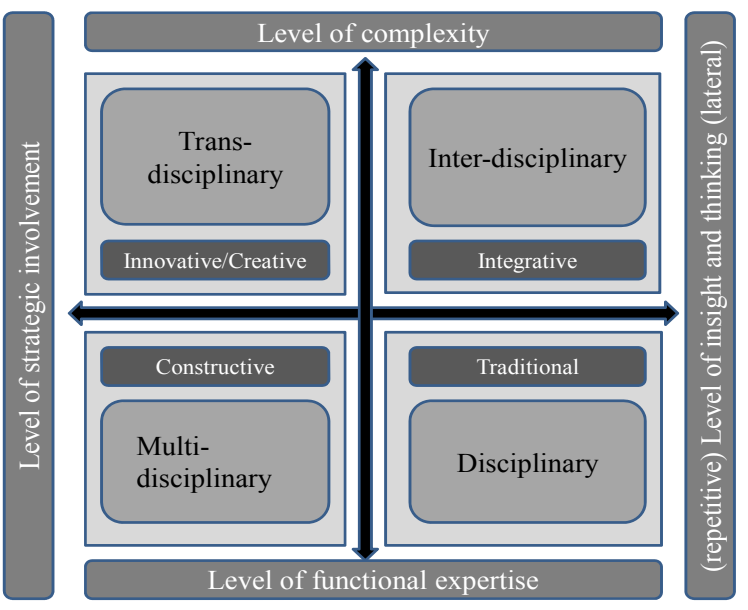

\section{Source: Own construction, 2011.}

Figure 2: $\quad$ Process of development of insight and thinking by practitioners in transportation planning, spatial planning and environmental management.

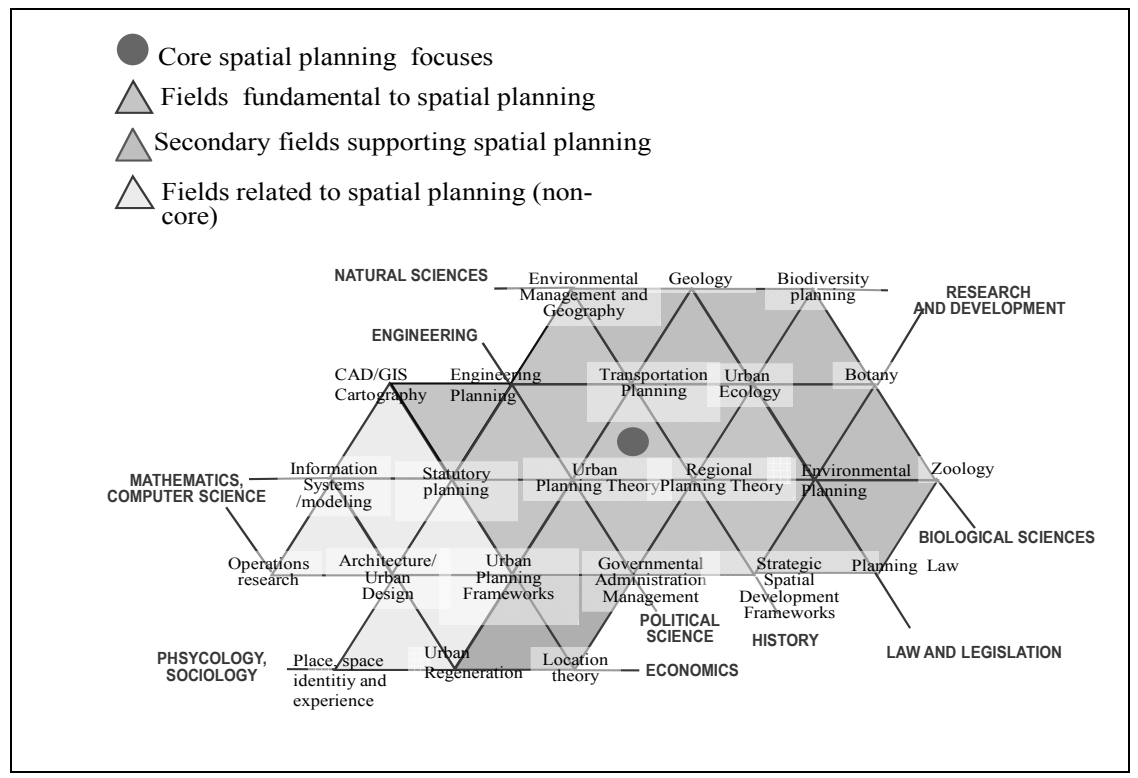

Source: Own construction, 2011.

Figure 3: Macro and micro subject areas within the education sector illustrating the interface relationships. 
Figure 3 illustrates the macro context of the educational and research relationships influencing the nature of the interface between transportation planning, spatial planning (inclusive of urban and regional planning) and environmental management.

Table 2 shows the level of management and functional involvement between transportation planning, spatial planning and environmental management based on the deductions of this paper and line of arguments presented thus far. From the table the activity category together with an assessment of the level of involvement are indicated. This process is based on the focus of the domain as discussed above, policy and the legislative framework applicable to each of the professions. This assessment is indicative if the interface between them. A distinction is made in classification between direct, indirect, application and no involvement categories.

Table 2: Assessment of the interface based on activity characterization.

\begin{tabular}{|c|c|c|c|c|}
\hline \multirow{6}{*}{$\begin{array}{l}\frac{\Phi}{E} \\
\frac{\bar{D}}{\text { O }} \\
\text { É }\end{array}$} & Intervention & Direct & None & Indirect \\
\hline & Monitoring & Indirect & Indirect & Indirect \\
\hline & Operation & None & None & Indirect \\
\hline & Implementation & None & Indirect & Direct \\
\hline & Project management & None & Indirect & Direct \\
\hline & Design & None & Direct & Direct \\
\hline \multirow{12}{*}{ 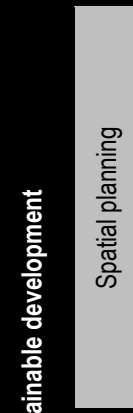 } & Feasibility & Indirect & Direct & Direct \\
\hline & Accessibility & None & Direct & Direct \\
\hline & Statutory planning & None & Direct & Indirect \\
\hline & Need and desirability & Direct & Direct & Direct \\
\hline & Services & Indirect & Direct & Direct \\
\hline & Movement patterns & Indirect & Direct & Direct \\
\hline & Settlement patterns & None & Direct & Direct \\
\hline & Socio-economic & Direct & Direct & Direct \\
\hline & Planning & Indirect & Direct & Direct \\
\hline & Integration & Indirect & Direct & Direct \\
\hline & Systems approach & Indirect & Direct & Direct \\
\hline & Strategy formulation & Direct & Direct & Direct \\
\hline 艿 & Leading & Direct & Indirect & Indirect \\
\hline & Coordinating & Direct & Indirect & Indirect \\
\hline & Organizing & Direct & Indirect & Application \\
\hline 蒿 & Life cycle & Direct & Indirect & Indirect \\
\hline$\frac{E}{\mathbb{D}}$ & Quality management & Direct & None & Indirect \\
\hline$\stackrel{\mathbb{Z}}{\complement}$ & Resource management & Direct & Indirect & Direct \\
\hline$\sum^{\pi}$ & Risk management & Direct & Indirect & Application \\
\hline & Controlling & Direct & Indirect & Application \\
\hline & Mitigation & Direct & Indirect & Application \\
\hline & Impact determination & Direct & Indirect & Indirect \\
\hline & Level of involvement & $\begin{array}{c}\text { Environmental } \\
\text { Management }\end{array}$ & $\begin{array}{l}\text { Urban and } \\
\text { Regional } \\
\text { Planning }\end{array}$ & $\begin{array}{l}\text { Transportation } \\
\text { planning }\end{array}$ \\
\hline
\end{tabular}

Source: Own construction (2010). 


\section{Planning process considerations between transportation planning, spatial planning and environmental management}

Table 3 shows the collaborative practice, management instruments and functional involvement between transportation planning, spatial planning and environmental management based on the content of the paper including the line of arguments generated thus far. From the Table 2 above the activity category together with an assessment of the level of involvement per disciplinary field area are indicated. This process is based on the focus of the domain as discussed above, policy and legislative framework applicable to each of the professions. The assessment as contained in Table 2 and Table 3 is thus indicative of the level of interface between them.

Table 3: $\quad$ Instruments in collaborative practice.

\begin{tabular}{|c|c|c|}
\hline ITP & SDF & Environmental Man. \\
\hline Integrated transport plans & Integrated development plans & $\begin{array}{c}\text { Environmental management } \\
\text { (ITP) }\end{array}$ \\
(IDP) & Strategic environmental \\
Traffic impact assessments & Housing sector plans (HSP) & assessments (SEA) \\
(TIA) & Sectoral Plans (SP) & Environmental impact \\
Accessibility studies (AS) & Precinct plans (PP) & assessment (EIA) \\
Traffic engineering plans & Urban regeneration plans. & Cumulative environmental \\
(TEP) & Urban design plans (UD) & assessments (CEA) \\
Route alignment & Spatial master plans (SMP) & Economic environmental \\
assessments (RAA) & Transportation planning/plans & assessments (EEA) \\
Public transport plans (PTP) & (TP) & Environmental mitigation plans \\
Transportation infrastructure & Site development plans & (EM) \\
plans (TIP) & (SDP) & Environmental management \\
High speed rail planning & Urban formalization plans & programmes (EMP) \\
(HSRP) & (UFP) & Heritage plans (HP) \\
Transportation economic & Land use management plans & Bioregional plans (BP) \\
analysis (TEA) & (LUMP) & Ecology plans (EP) \\
Transportation master plans & Spatial development & Integrated environmental \\
(TMP) & frameworks (SDF) & management (IEM) \\
Transportation modeling & Statutory planning (SP) & Biodiversity plans (BDP) \\
(TM) & Potential development & Environmental impact \\
Traffic demand management & analysis (PDA) & mitigation plans (EIMP) \\
(TDM) & & \\
Traffic access management & & \\
(TAM) & & \\
\hline
\end{tabular}

Source: Own construction.

From Table 3 and Figure 4 the planning instruments in terms of plan classification used in ITP, SDF and Environmental Management practice is evident. The need to formalize integration and collaboration practices is thus a necessity in the light of the underlying complexities contained in each of the instruments. The result if not implemented is duplication, confusion and disjointedness in the planning processes. 


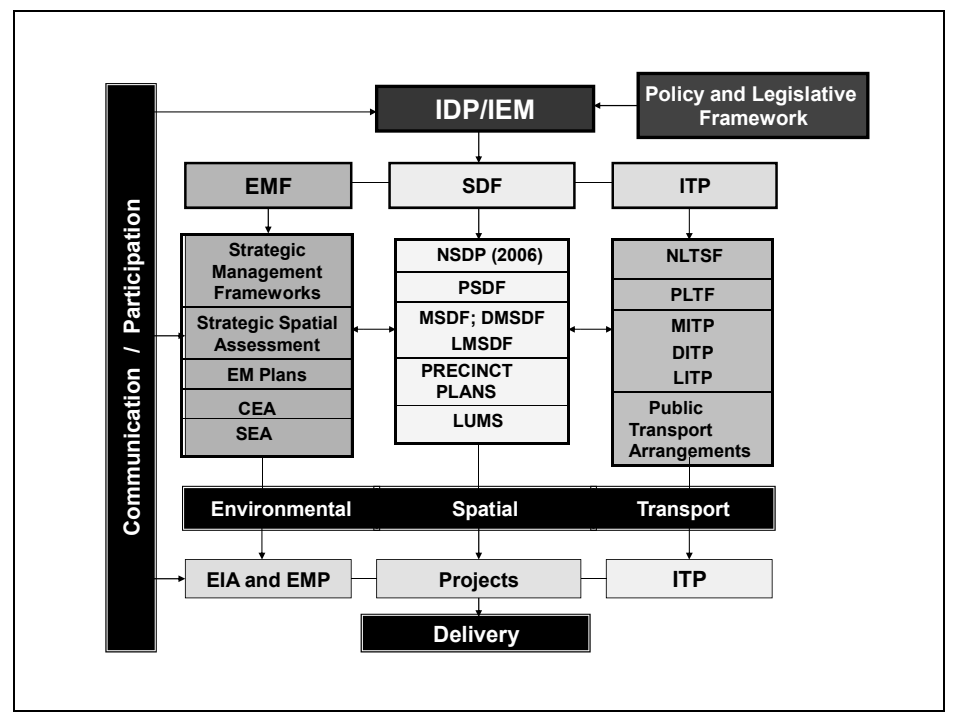

Source: Own construction (2010).

Figure 4: $\quad$ Process relationships between processes within professions.

\section{Conclusions and recommendations}

From the contents above the following conclusions can be drawn:

- The application of practices that serves the objectives of transportation planning, spatial planning and environmental management serves as the main reason for the disjointedness in attaining sustainable development within spatial systems.

- The disjuncture is due to focuses that serves the interest of a particular profession only. In the 'battle for turf' each of the professions functions primarily within its own guiding policy and legislative framework.

- Professional integration becomes then the role and function of the government sector as adjudicator that impacts negatively on delivery and sustainable development.

- Capacity building amongst professions will promote integration in plan formulation and project implementation.

- Improved alignment of the applicable policy and legislative frameworks will promote sustainable planning and development.

- The alignment of education, training and professional practices is required if the impediments in terms of the professional domain as illustrated in this paper is to be addressed.

- The application of integrated simulation, modelling techniques and methodologies to be informed by transportation planning, spatial 
planning and environmental management practitioners will improve alignment and sustainable planning and development.

- Formulation of trans-disciplinary plans to integrate and align plan formulation amongst the professions supported by integrated policy and legislative frameworks.

\section{References}

[1] National Development and Planning Commission: Draft Green Paper on Development and Planning. Pretoria. (1999)

[2] Republic of South Africa: Development Facilitation Act (Act 67 of 1995). Pretoria. Government Printer. (1995)

[3] Republic of South Africa: Constitution of the Republic of South Africa. (Act 108 of 1996). Pretoria. Government Printer. (1996)

[4] Republic of South Africa: Urban Transport Act (Act 78 of 1977). Pretoria. Government Printer. (1977)

[5] Republic of South Africa: National Land Transport Transition Act (Act 22 of 2002). Pretoria. Government Printer. (2000)

[6] Republic of South Africa: National Land Transport Act (Act 5 of 2009). Pretoria. Government Printer. (2009)

[7] Republic of South Africa: White Paper on National Transport Policy. Government Printer. Pretoria. Pretoria. Government Printer. (1996)

[8] Republic of South Africa: Moving South Africa-The Action Agenda. Pretoria. Departmental publication. (1999)

[9] Republic of South Africa: Rural Transport Strategy for South Africa. Pretoria. Departmental publication. (2003)

[10] Republic of South Africa: National Transport Master Plan. Natmap 2050. Background Document. Online documents at URL http://www.transport.gov.za (02-03-2009)

[11] Dewar, D., Todes A. and Watson V. Urbanisation and Settlement Policy in South Africa: Some Findings and Recommendations Urban Problems Research Unit. University of Cape Town. Cape Town. (1985)

[12] Tomlinson, R.: Urbanization in Post Apartheid South Africa. London. Unwin Hyman. (1990)

[13] Swilling M.: Introduction. (In M Swilling, R Humphries \& K Shubane (eds) Apartheid City in Transition). Cape Town. Oxford University Press. (1991)

[14] MABIN, A and SMIT, D.: Reconstructing South African Cities? The Making of Urban Planning 1900 - 2000. In Planning Perspectives, Volume 12 (1997)

[15] PLANACT.: Integrated Development Planning - A Manual for Community Leaders. Braamfontein. (1988)

[16] Tilman, H. and Wall, R.: (In: Housing Generator -Integration or Fragmentation. Rotterdam. Drukkerij van Oriel). (1997) 
[17] Dewar, D. and Todeschini, F.: Urban Management and Economic Integration in South Africa. Cape Town. Francolin Publishers (Pty) Ltd. (1999)

[18] CSIR.: Housing is not about Houses-the Boutek Experience. Published by the CSIR Building Construction Technology. Pretoria. (2000)

[19] GOVERNMENT of SOUTH Africa.: White Paper on Spatial Planning and Land Use Management. Pretoria: Government Printer. (2001)

[20] The Presidency.: National Spatial Development Perspective. Pretoria. Published by The Presidency. RSA. (2003); (2006)

[21] Republic of South Africa: Final Draft Land Use Management Bill. Pretoria. Government Printer. (2008)

[22] Republic of South Africa: Local Government: Municipal Structures Act. (Act 117 of 1998). Pretoria. Government Printer. (1998)

[23] Republic of South Africa: Local Government: Municipal Systems Act. (Act 32 of 2000). Pretoria. Government Printer. (2000)

[24] Republic of South Africa: Environment Conservation Act, 1989 (Act No. 73 of 1989). Pretoria. Government Printer. (2000)

[25] Sowman, R. Fuggle, R. and Preston, G.: A review of the evolution of environmental evaluation procedures in South Africa. Environmental Impact Review, No.15. (1995)

[26] Council for the Environment.: Integrated Environmental Management in South Africa. Pretoria. Joan Lotter Publications. (1989)

[27] Republic of South Africa: National Environmental Management Act (Act 107 of 1998). Pretoria. Government Printer. (1998)

[28] DEAT: Overview of Integrated Environmental Management, Integrated Environmental Management, Information Series 0, Department of Environmental Affairs and Tourism (DEAT). Pretoria. (2004)

[29] Republic of South Africa: Regulations in terms of Chapter 5 of the National Environmental Management Act, 1998. Regulation R.385. Pretoria. Government Printer. (2006)

[30] Republic of South Africa: Regulations in terms of Chapter 5 of the National Environmental Management Act, 1998. Regulations R.543 to R.547). Pretoria. Government Printer. (2010)

[31] Department of Environment and Tourism: A National Framework for Sustainable Development in South Africa. Departmental Publication. Pretoria. (2008)

[32] Fry, G., Tress, B. and Tress, G.: Integrative landscape research: facts and challenges. (In: Wu, J. and Hobbs, R.J. (eds). Key topics in Landscape Ecology). New York. Cambridge University Press. (2007) 